\section{- OPEN ACCESS}

\title{
Effective silencing of ENaC by siRNA delivered with epithelial-targeted nanocomplexes in human cystic fibrosis cells and in mouse lung
}

\author{
Aristides D Tagalakis, ${ }^{1}$ Mustafa M Munye, ${ }^{1}$ Rositsa Ivanova, ${ }^{2}$ Hanpeng Chen, ${ }^{3}$ \\ Claire M Smith, ${ }^{4}$ Ahmad M Aldossary, ${ }^{1}$ Luca Z Rosa, ${ }^{1}$ Dale Moulding, ${ }^{5}$ \\ Josephine L Barnes, ${ }^{6}$ Konstantinos N Kafetzis, ${ }^{1}$ Stuart A Jones, ${ }^{3}$ Deborah L Baines, ${ }^{7}$ \\ Guy W J Moss, ${ }^{2}$ Christopher O'Callaghan, ${ }^{4}$ Robin J McAnulty, ${ }^{6}$ Stephen L Hart ${ }^{1}$
}

\begin{abstract}
- Additional material is published online only. To view please visit the journal online (http://dx.doi.org/10.1136/ thoraxjn-2017-210670)
\end{abstract}

${ }^{1}$ Experimental and Personalised Medicine Section, UCL Great Ormond Street Institute of Child Health, London, UK

${ }^{2}$ Department of Neuroscience, Physiology and Pharmacology, University College London, London, UK

${ }^{3}$ Institute of Pharmaceutical Science, Faculty of Life Science and Medicine, King's College London, London, UK

${ }^{4}$ Respiratory, Critical Care and Anaesthesia, UCL Great Ormond Street Institute of Child Health, London, UK

${ }^{5} \mathrm{UCL}$ Great Ormond Street Institute of Child Health, London, UK

${ }^{6}$ UCL Respiratory Centre for Inflammation and Tissue Repair, London, UK

${ }^{7}$ Institute of Infection and Immunity, St George's University of London, London, UK

Correspondence to Dr Aristides D Tagalakis, Experimental and Personalised Medicine Section, UCL Great Ormond Street Institute of Child Health, London WC1N 1EH, UK: Aristides.Tagalakis@edgehill. ac.uk

Received 20 June 2017 Revised 8 April 2018 Accepted 9 April 2018

Published Online First

10 May 2018

\section{ABSTRACT \\ Introduction Loss of the cystic fibrosis transmembrane conductance regulator in cystic fibrosis (CF) leads to hyperabsorption of sodium and fluid from the airway due to upregulation of the epithelial sodium channel (ENaC). Thickened mucus and depleted airway surface liquid (ASL) then lead to impaired mucociliary clearance. $\mathrm{ENaC}$ regulation is thus a promising target for CF therapy. Our aim was to develop siRNA nanocomplexes that mediate effective silencing of airway epithelial $\mathrm{ENaC}$ in vitro and in vivo with functional correction of epithelial ion and fluid transport.}

Methods We investigated translocation of nanocomplexes through mucus and their transfection efficiency in primary CF epithelial cells grown at airliquid interface (ALI).Short interfering RNA (SiRNA)mediated silencing was examined by quantitative RT-PCR and western analysis of ENaC. Transepithelial potential $\left(V_{t}\right)$, short circuit current $\left(I_{s c}\right), A S L$ depth and ciliary beat frequency (CBF) were measured for functional analysis. Inflammation was analysed by histological analysis of normal mouse lung tissue sections.

Results Nanocomplexes translocated more rapidly than siRNA alone through mucus. Transfections of primary CF epithelial cells with nanocomplexes targeting $\alpha \mathrm{ENaC}$ siRNA, reduced $\alpha E N a C$ and $\beta E N a C$ mRNA by $30 \%$. Transfections reduced $\mathrm{V}_{t}$, the amiloride-sensitive I and mucus protein concentration while increasing ASL depth and CBF to normal levels. A single dose of siRNA in mouse lung silenced $\mathrm{ENaC}$ by approximately $30 \%$, which persisted for at least 7 days. Three doses of siRNA increased silencing to approximately $50 \%$.

Conclusion Nanoparticle-mediated delivery of ENaCsiRNA to ALI cultures corrected aspects of the mucociliary defect in human CF cells and offers effective delivery and silencing in vivo.

\section{INTRODUCTION}

Cystic fibrosis (CF) is caused by mutations in the CF transmembrane conductance regulator gene (CFTR), which encodes a cyclic AMP-activated channel for chloride and other anions. ${ }^{12}$ Mutations in CFTR also result in upregulation of the epithelial sodium channel ( $\mathrm{ENaC})$, leading to imbalanced water and ion movement across the airway epithelium. $^{3}{ }^{4}$ This results in depletion of the airway

\section{Key messages}

What is the key question?

- Can silencing of the airway epithelial sodium channel (ENaC) activity correct the mucociliary defects associated with the cystic fibrosis (CF) epithelium?

What is the bottom line?

- Short interfering RNA (SiRNA)-mediated silencing of $\mathrm{ENaC}$ in vitro in pseudostratified, ciliated, air-liquid interface (ALI) models of the human airway was shown to correct the electrical and mucociliary defects associated with the CF epithelium, and in addition, we demonstrated efficiency of delivery in vivo to murine lung and accumulation of the level of silencing by repeated delivery along with safety by analysis of inflammation.

Why read on?

- We have described a siRNA nanoparticle formulation that penetrates mucus to transfect CF epithelial cells at ALI, and following repeated transfection both at $A L I$ and in vivo demonstrated cumulative $\mathrm{ENaC}$ silencing to achieve the desired functional effect, providing evidence to support its further development as a novel therapeutic approach.

surface liquid (ASL) and thickened mucus with progressive loss of pulmonary function. ${ }^{3}{ }^{4}$ Therefore, $\mathrm{ENaC}$ is a promising therapeutic target for $\mathrm{CF}$ with the potential to restore lung fluid homeostasis and thus improve mucociliary clearance. $\mathrm{ENaC}$ is comprised of $\alpha, \beta$ and $\gamma$ subunits. The poreforming $\alpha \mathrm{ENaC}$ subunit is required for full channel function. The $\beta$ and $\gamma$ subunits are regulators of $\mathrm{ENaC}$ activity, ${ }^{56}$ and residual $\mathrm{ENaC}$ activity can be measured in their absence. ${ }^{57}$ The other $\mathrm{ENaC}$ subunit, $\delta$, is only expressed at low levels in the lung of humans and not at all in rodents. ${ }^{8}$

Small molecule $\mathrm{ENaC}$ inhibitors such as amiloride ${ }^{9}$ and benzamil ${ }^{10}$ reduce sodium uptake, but their effects are short-lived because of drug absorption. ${ }^{11}$ Silencing of $\mathrm{ENaC}$ expression, by short interfering RNA (siRNA)-mediated RNA 
A

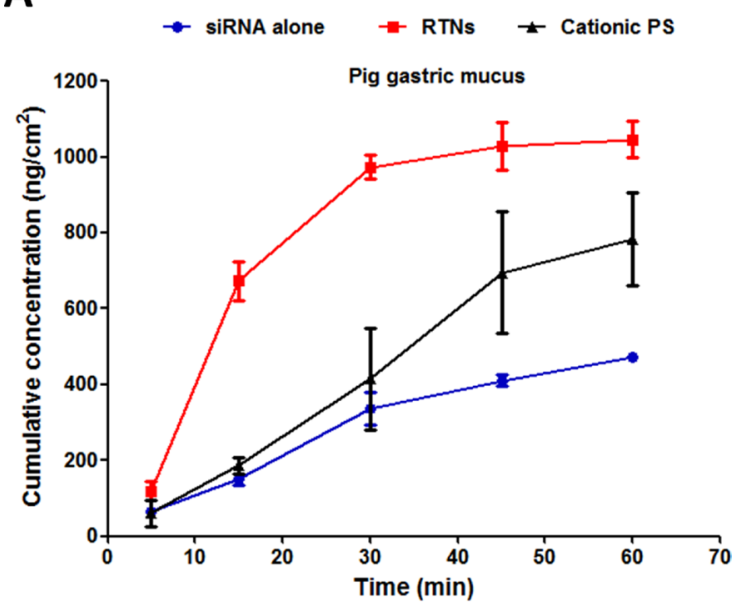

B

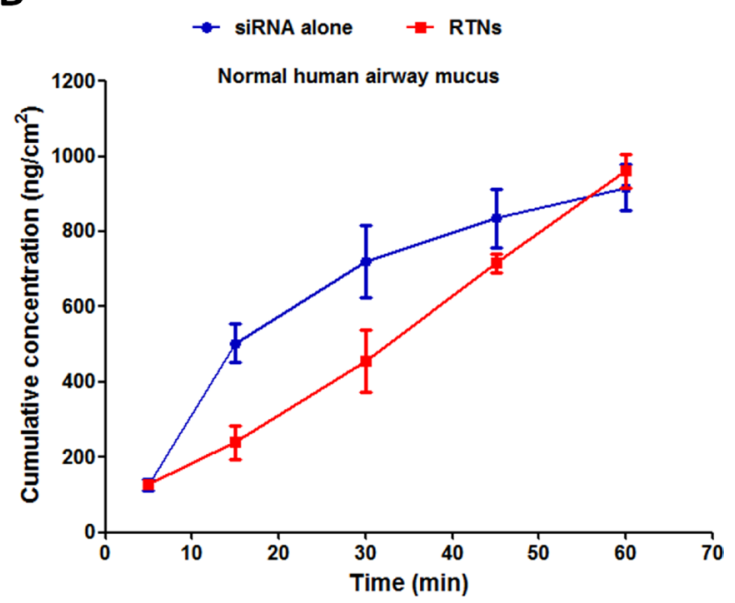

c

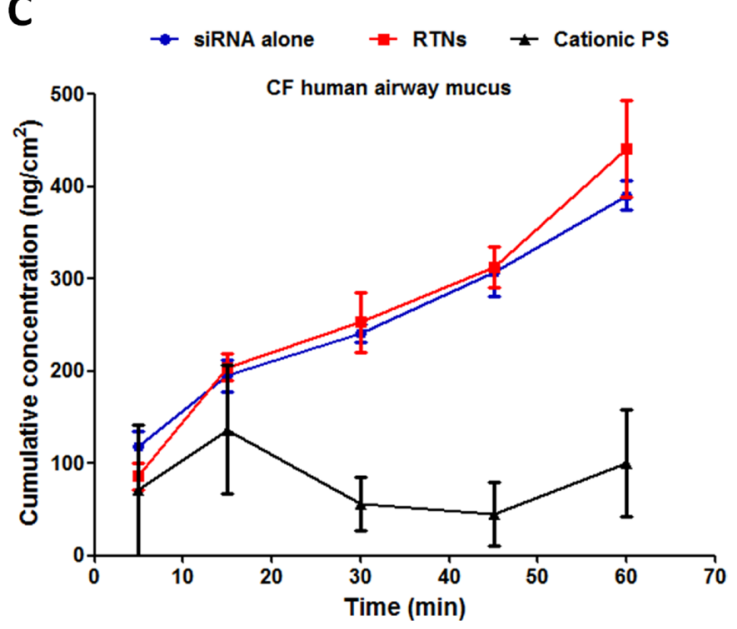

Figure 1 Nanoparticles translocate vertically through the mucus barrier. Cy3-siRNA alone, RTNs containing Cy3-siRNA or fluorescent polystyrene (PS) nanoparticles were investigated for their translocation potential through $(A)$ pig gastric mucus, $(B)$ normal human airway mucus and (C) CF human airway mucus. The siRNA that is labelled with Cy3 is targeting glyceraldehyde 3-phosphate dehydrogenase (GAPDH). The experiments were repeated on three occasions, and each point is the mean \pm SEM of triplicate measurements. CF, cystic fibrosis; RTNs, receptor-targeted nanocomplexes; siRNA, short interfering RNA.

interference, offers a more promising therapeutic route. ${ }^{12-14}$ Potential advantages of nanoparticle-mediated siRNA therapy include its potency, specificity, duration ${ }^{15}$ and restriction to the airways to prevent nephrotoxicity. Transfection of the CF airway epithelium requires protection of siRNA from nucleases, penetration of the mucus and periciliary liquid layer (PCL) and targeted uptake by the epithelial cells ${ }^{16}$ with purpose-designed nanoparticles. Previous attempts to develop ENaC siRNA therapies ${ }^{17} 18$ were limited by lack of nanoparticles capable to effectively deliver siRNA to the airway epithelium.

Receptor-targeted nanocomplexes (RTNs) comprise multifunctional mixtures of cationic liposomes (L) and cationic targeting peptides (P) that self-assemble, electrostatically on mixing with siRNA (R). ${ }^{19-24}$ Peptide E packages nucleic acids through a cationic, oligolysine domain and mediates epithelial receptor targeting through a seven-amino acid motif, SERSMNF, derived by biopanning of a phage peptide library. ${ }^{25}$ The targeting peptide displays close similarity to receptor binding proteins of two intracellular pathogens, rhinovirus and Listeria monocytogenes. ${ }^{26}$ Rhinoviruses bind intercellular adhesion molecule-1 that is present in the airway epithelium and upregulated in the inflamed CF epithelium. ${ }^{27}{ }^{28}$ Following receptor-mediated endocytosis, the liposome component destabilises the endosomal bilayer allowing nucleic acid release to the cytoplasm before endosomal degradation occurs. ${ }^{29}$ This peptide has been used previously for targeted transfection with plasmid DNA, ${ }^{25}$ minicircle $\mathrm{DNA}^{30}$ and siRNA ${ }^{31}$ of bronchial epithelial cells in vitro and in vivo.

In this study, we have investigated the effects of RTN-mediated delivery of $\alpha \mathrm{ENaC}$ siRNA on pseudostratified, ciliated, air-liquid interface (ALI) models of the human CF airway, particularly the correction of the electrical and mucociliary defects associated with the CF epithelium. Finally, we have investigated the translational potential of this therapy by delivery of murine $\alpha \mathrm{ENaC}$ siRNA to the lungs of normal mice to assess in vivo transfection efficacy in a surrogate model of the human lung, including efficacy of repeated delivery as well as safety by analysis of inflammation.

\section{MATERIALS AND METHODS}

Full details are available in the online supplementary material.

\section{Statistics}

Data are expressed as the mean \pm SEM and analysed using a two-tailed, unpaired Student's t-test or one-way analysis of variance (ANOVA) and Bonferroni's post hoc analysis where applicable. We also report other data as median and interquartile range (IQR), and these have been analysed using a non-parametric Mann-Whitney U test.

\section{RESULTS}

\section{Assessment of nanocomplex translocation through mucus}

Nanocomplexes containing Cy3-labelled siRNA were added to the surface of the mucus, then the cumulative concentration of fluorophores diffusing through the mucus into the lower collection chamber over $60 \mathrm{~min}$ was measured and compared with siRNA alone and fluorescent cationic, polystyrene (PS) nanoparticles. The concentration of RTNs penetrating through the CF human airway mucus barrier at 1 hour (figure $1 \mathrm{C}$ and online supplementary table S1) $\left(441.1 \pm 52.7 \mathrm{ng} / \mathrm{cm}^{2}\right)$ was $46 \%$ of that collected from the normal human airway mucus barrier at 1 hour $\left(961.5 \pm 44.8 \mathrm{ng} / \mathrm{cm}^{2}\right.$; figure $\left.1 \mathrm{~B}\right)$, and this was similar for siRNA alone at $43 \%\left(390.1 \pm 15.8 \mathrm{ng} / \mathrm{cm}^{2}\right.$ through CF human airway mucus and $917.3 \pm 60.1 \mathrm{ng} / \mathrm{cm}^{2}$ through normal human airway mucus). RTN and siRNA penetration through normal mucus were similar at 1 hour (figure $1 B)(p>0.05, n=6)$, whereas 
Table 1 A comparison of the nanoparticle effective diffusion rate in mucus $\left(D_{m}\right)$ and the effective diffusion rate in water $\left(D_{w}\right)$ of the receptortargeted nanocomplexes (RTNs), polystyrene (PS) nanoparticles and siRNA alone through three different types of static layers of mucus. $D_{m} / D_{w}$ is the relative restriction of diffusion in mucus compared with water.

\begin{tabular}{|c|c|c|c|c|c|c|}
\hline Particle & $\begin{array}{l}\text { Diffusion in PGM } \\
\left(\mathrm{cm}^{2} \mathrm{~s}^{-1}\right)\end{array}$ & $D_{m} / D_{w}(P G M)$ & $\begin{array}{l}\text { Diffusion in NM } \\
\left(\mathrm{cm}^{2} \mathrm{~s}^{-1}\right)\end{array}$ & $\mathrm{D}_{\mathrm{m}} / \mathrm{D}_{\mathrm{w}}(\mathrm{NM})$ & $\begin{array}{l}\text { Diffusion in CFM } \\
\left(\mathrm{cm}^{2} \mathrm{~s}^{-1}\right)\end{array}$ & $D_{m} / D_{w}$ (CFM) \\
\hline siRNA & $3.75 \times 10^{-9}$ & $1.57 \times 10^{-2}$ & $1.31 \times 10^{-8}$ & $1.11 \times 10^{-2}$ & $2.33 \times 10^{-9}$ & $2.66 \times 10^{-3}$ \\
\hline RTNs & $1.38 \times 10^{-8}$ & $1.93 \times 10^{-1}$ & $8.71 \times 10^{-9}$ & $9.12 \times 10^{-2}$ & $2.67 \times 10^{-9}$ & $3.74 \times 10^{-2}$ \\
\hline PS & $5.75 \times 10^{-9}$ & $4.82 \times 10^{2}$ & - & - & $\mathrm{N} / \mathrm{A}$ & $\mathrm{N} / \mathrm{A}$ \\
\hline
\end{tabular}

CFM, cystic fibrosis human airway mucus; N/A, data not applicable as effective translocation was not achieved; NM, normal human airway mucus; PGM, pig gastric mucus; PS, polystyrene; RTN, receptor-targeted nanocomplex; siRNA, short interfering RNA.

in porcine gastric mucus, the RTNs penetrated more rapidly than siRNA (figure 1A) $\left(1046.1 \pm 47.6 \mathrm{ng} / \mathrm{cm}^{2}\right.$ and $472.0 \pm 8.8 \mathrm{ng} / \mathrm{cm}^{2}$ for RTNs and siRNA alone, respectively; $\mathrm{p}<0.01, \mathrm{n}=6$ ). The rate of penetration of pig gastric mucus by cationic PS nanoparticles $(55.0 \pm 2.1 \mathrm{~nm}$ and $+23.1 \pm 1.1 \mathrm{mV})$ was not significantly different to siRNA alone (figure $1 \mathrm{~A} ; 782.7 \pm 123.0 \mathrm{ng} / \mathrm{cm}^{2}$ and $472.0 \pm 8.8 \mathrm{ng} / \mathrm{cm}^{2}$ for PS nanoparticles and siRNA alone, respectively at 1 hour), but in CF mucus, PS nanoparticles were significantly slower than RTNs or siRNA (figure $1 \mathrm{C} ; 100.0 \pm 57.6 \mathrm{ng}$ / $\mathrm{cm}^{2}$ for PS nanoparticles at 1 hour compared with the concentrations displayed above which were $\sim 4$-fold more for both RTNs and siRNA alone; $\mathrm{p}<0.05, \mathrm{n}=6$ ).

Diffusion coefficients in the three types of mucus $\left(D_{m}\right)$ and water $\left(D_{w}\right)$ were calculated as described in the Methods section. $\mathrm{D}_{\mathrm{m}} / \mathrm{D}_{\mathrm{w}}$ is the relative restriction of diffusion in mucus compared with water (table 1). The diffusion of RTNs was 14 -fold higher than that of siRNA alone in CF mucus (27-fold impedance for RTNs compared with 376-fold impedance for siRNA alone) despite the nanoparticles being significantly larger $(91.9 \pm 0.5 \mathrm{~nm})$ and more cationic $(+35.1 \pm 0.6 \mathrm{mV})$ than siRNA, which is approximately $7.5 \mathrm{~nm} .{ }^{32}$ RTNs penetrated normal human mucus and pig gastric mucus 8.2-fold and 12.3-fold faster, respectively, than siRNA alone (table 1).

\section{In vitro siRNA silencing of $\mathrm{ENaC}$ in epithelial cells}

Peptide-targeted cationic nanocomplexes were then used to transfect 16HBE14o- epithelial cells with siRNA targeting $\alpha \mathrm{ENaC}$. Western blot analysis of $\alpha \mathrm{ENaC}$ protein showed that transfection of $16 \mathrm{HBE} 14 \mathrm{o}-$ cells with RTNs at $75 \mathrm{nM}$ siRNA led to a decrease in the abundance of both the $90 \mathrm{kDa}$ and the $65 \mathrm{kDa}$ $\alpha \mathrm{ENaC}$ protein bands by $41 \%$ and $48 \%$, respectively, compared with those transfected with control siRNA (online supplementary figure $\mathrm{S} 1 \mathrm{~A}, \mathrm{~B})$.

Expression of $\alpha \mathrm{ENaC}$ in $B M I-1$ transduced $\mathrm{CF}$ bronchial epithelial (CFBE) cells ${ }^{33}$ attained maximal levels after 2-5 days in ALI cultures (figure 2A), and so, ALI culture transfections in ongoing experiments were performed after at least 5 days ALI culture. Transfections of CFBE monolayers with $100 \mathrm{nM} \alpha \mathrm{ENaC}$ siRNA reduced $\alpha \mathrm{ENaC}$ mRNA by $30 \%(\mathrm{n}=3)$ compared with control siRNA-treated cultures (figure 2B). After three sequential transfections, performed at 48 hours intervals, the level of silencing was improved to $54 \%(n=3$; figure $2 B)$. Silencing of $\alpha \mathrm{ENaC}$ also resulted in a $51 \%$ silencing of $\beta \mathrm{ENaC}$ $(n=3$; online supplementary table S2) but not the $\gamma$ subunit (figure 2C). The $\alpha$ subunit in CFBE cells was 74.9-fold and 19.7fold overexpressed relative to the $\gamma$ and $\beta$ subunits, respectively (online supplementary figure $\mathrm{S} 2, \mathrm{n}=3$ ).

\section{Functional effects of $\mathrm{ENaC}$ silencing}

We next investigated the effects of $\alpha \mathrm{ENaC}$ silencing on amiloride-sensitive ENaC-mediated short circuit current $\left(\mathrm{I}_{\mathrm{sc}}\right)$ in
CFBE cells cultured at ALI 2 days after transfection (figure 3A). The amiloride-sensitive $\mathrm{I}_{\mathrm{sc}}$ was reduced in cells treated with $\alpha \mathrm{ENaC}$ siRNA (median: $6.4 \mu \mathrm{A} / \mathrm{cm}^{2}$; IQR: $5.4-9.8 \mu \mathrm{A} / \mathrm{cm}^{2}$; $\mathrm{n}=6$ ) compared with control siRNA (median: $11.5 \mu \mathrm{A} / \mathrm{cm}^{2}$; IQR: $\left.10.1-14.1 \mu \mathrm{A} / \mathrm{cm}^{2} ; \mathrm{p}<0.05, \mathrm{n}=8\right)$ or untreated cells (median: $14.3 \mu \mathrm{A} / \mathrm{cm}^{2}$; IQR: 13.2-17.9 $\mu \mathrm{A} / \mathrm{cm}^{2} ; \mathrm{p}<0.01, \mathrm{n}=5$ ) (figure 3B,C; online supplementary table S3). As expected, CFBE cells showed a very limited response to forskolin (a cAMP agonist) or GlyH-101 (a CFTR inhibitor) under any of the conditions examined (figure $3 \mathrm{~B}$ ) as opposed to normal human bronchial epithelial (NHBE) cells (online supplementary figure S3). Transepithelial electrical resistance $\left(R_{t}\right)$ was not perturbed by the transfection procedure (online supplementary figure S4), with ENaC-silenced cells having a median of 693.5 (IQR: 565.7-805.8) $\Omega \mathrm{cm}^{2}(\mathrm{n}=7)$ compared with 783.2 (IQR: 711.1-953.2) $\Omega \mathrm{cm}^{2}$ and 676.7 (IQR: 653.1-744.2) $\Omega \mathrm{cm}^{2}$ for control siRNA $(n=7)$ and untreated cells $(n=3)$, respectively (online supplementary table S3).

We then performed three sequential siRNA transfections of CFBE cells at 48-hour intervals and determined physiological responses to $\mathrm{ENaC}$ silencing. Mucus was not removed during this period (unwashed cells). Samples treated with $\alpha \mathrm{ENaC}$ siRNA had lower negative transepithelial potentials $\left(V_{t}\right)$ (median: $-7.2 \mathrm{mV}$; IQR: $-5.7 \mathrm{mV}$ to $-12.2 \mathrm{mV}$ ) than those transfected with control siRNA (median: $-16.0 \mathrm{mV}$; IQR: $-14.8 \mathrm{mV}$ to $-19.0 \mathrm{mV}$ ) (figure $3 \mathrm{D} ; \mathrm{n}=5$ ) as measured by scanning ion-conductance microscopy. The median $\mathrm{V}_{\mathrm{t}}$ value for the $\mathrm{VX}-770$ and VX-809-treated CF cells was $-6.8 \mathrm{mV}$ (IQR: $-6.7 \mathrm{mV}$ to $-12.7 \mathrm{mV}$ ), while for untreated, non-CF cells, it was $-7.7 \mathrm{mV}$ (IQR: $-6.3 \mathrm{mV}$ to $-11.6 \mathrm{mV}$; online supplementary table S4).

The ASL depth in CFBE ALI cultures was increased by $\sim 1.5$ fold (median: $12.1 \mu \mathrm{m}$; IQR: $10.7-14.9 \mu \mathrm{m}$ ) after silencing of $\alpha \mathrm{ENaC}$ compared with control siRNA-treated (median: $7.9 \mu \mathrm{m}$; IQR: $6.4-9.8 \mu \mathrm{m}$ ) and untreated cells (median: $8.2 \mu \mathrm{m}$; IQR: $5.8-11.1 \mu \mathrm{m})(\mathrm{p}<0.001, \mathrm{n}=4)$ (figure $4 \mathrm{~A}, \mathrm{~B}$; online supplementary table S4). The ciliary beat frequency (CBF) of unwashed CFBE cells increased to $14.5 \pm 0.5 \mathrm{~Hz}$ from $9.6 \pm 0.7 \mathrm{~Hz}$ in untreated CFBE cultures following sequential treatment with $\alpha \mathrm{ENaC}$ siRNA $(\mathrm{p}<0.001, \mathrm{n}=10)$, compared with $11.9 \pm 1.0 \mathrm{~Hz}$ in control siRNA-treated cells $(\mathrm{p}<0.05, \mathrm{n}=10)$ (figure $4 \mathrm{C})$. The CBF of VX-770 and VX-809-treated cells was also increased to $12.8 \pm 0.5 \mathrm{~Hz}(\mathrm{p}<0.05, \mathrm{n}=10$; online supplementary table $\mathrm{S} 4)$.

Cells treated with $\alpha \mathrm{ENaC}$ siRNA displayed reduced net fluid absorption rates from the apical side of the epithelium with a median value of $0.9 \mu \mathrm{L} / \mathrm{cm}^{2} /$ hour (IQR: $0.6-1.3 \mu \mathrm{L} / \mathrm{cm}^{2} /$ hour), which was lower than that of both control siRNA-treated cells (median: 1.6; IQR: 1.3-1.9 $\mu \mathrm{L} / \mathrm{cm}^{2} /$ hour; $\mathrm{p}<0.05, \mathrm{n}=4$ ) and untreated cells at $1.5 \mu \mathrm{L} / \mathrm{cm}^{2} /$ hour (IQR: $1.1-1.9 \mu \mathrm{L} / \mathrm{cm}^{2}$ ) hour; figure 4D; online supplementary table S4). Finally, we measured the total protein concentration in mucus collected from each well of the sequentially transfected CF monolayers. 
A

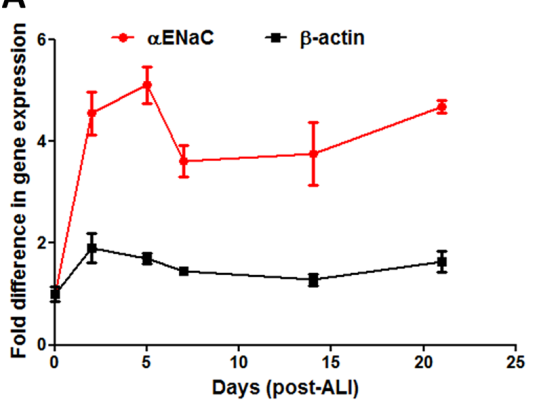

B

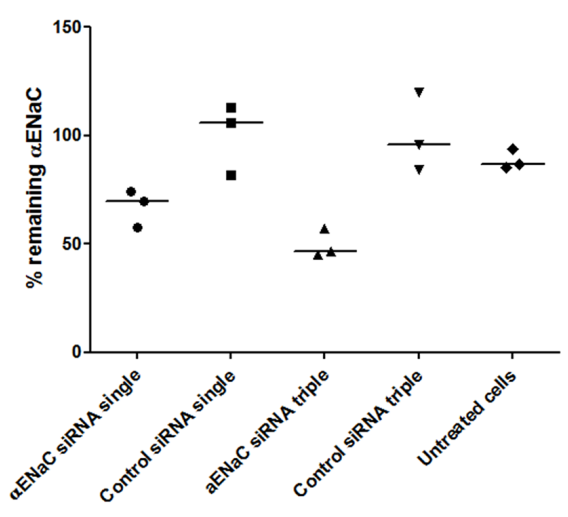

C

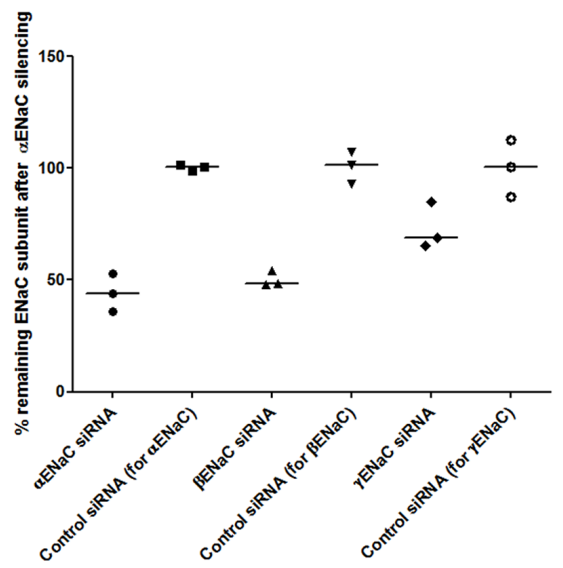

Figure $2 \mathrm{ENaC}$ expression over time of primary cells growing at $\mathrm{ALI}$ and silencing of $\mathrm{ENaC}$. (A) The fold-difference in endogenous $\alpha \mathrm{ENaC}$ gene expression relative to $\beta$-actin was quantified by qRT-PCR in CFBE cells from the start date of ALI cultures (mean of $n=3$ per time point). Points represent mean values \pm SEM. (B) RTN formulations containing either $\alpha \mathrm{ENaC}$ siRNA or control siRNA at $100 \mathrm{nM}$ were used in transfections of CFBE cells grown at ALI for 6 weeks. Transfections were performed once (single) or sequentially every other day (triple), and the percentage of silencing was calculated 48 hours after the last transfection ( $\mathrm{n}=3$ per formulation). The middle horizontal lines represent the median values. Silencing is normalised to the mean control siRNA set at $100 \%$. (C) CFBE cells grown at ALI were triple-transfected with RTN formulations containing either $\alpha E N a C$ siRNA or control siRNA at $100 \mathrm{nM}$, and the percentage of silencing of $\alpha, \beta$ and $\gamma \mathrm{ENaC}$ subunits was then calculated 48 hours after transfection ( $n=3$ per formulation). The middle horizontal lines represent the median values. Silencing is normalised to the mean control siRNA set at $100 \%$. Non-parametric Mann-Whitney U tests were performed, and no statistical significant differences were achieved. ALI, air-liquid interface; CFBE, cystic fibrosis bronchial epithelial cells; ENaC, epithelial sodium channel; RTN, receptor-targeted nanocomplex; siRNA, short interfering RNA.
The apical surface of each well was washed with PBS 2 days after the first (figure 5A) and second transfections (figure 5B) and 7 days after the third (figure 5C) transfection. In all cases, the protein concentration in mucus from the $\alpha \mathrm{ENaC}$-silenced cells $(n=6)$ was significantly lower than that from the control siRNA-treated cells $(\mathrm{n}=6), \mathrm{VX}-770$ and VX-809-treated cells $(n=4)$ or untreated cells $(n=3)$, and this effect lasted for at least 7 days post-transfection. At the end of the experiment, at 8 days post-transfection with $\alpha \mathrm{ENaC}$ siRNA $(\mathrm{n}=6), \alpha \mathrm{ENaC}$ expression was still $27 \%$ lower than control siRNA-treated cells $(\mathrm{p}<0.05$; figure $5 \mathrm{D})$.

\section{In vivo lung delivery}

We then investigated delivery of siRNA into the lungs of normal mice to assess the translational potential of $\alpha \mathrm{ENaC}$ siRNA delivery. The biodistribution analysis of nanocomplexes containing Dy677-labelled siRNA 24hours after oropharyngeal instillation showed very high retention of siRNA in lungs (figure 6A) with low-level fluorescence in intestines (online supplementary figure $\mathrm{S} 5, \mathrm{p}<0.05, \mathrm{n}=3$ ) which probably reflects incidental swallowing during administration. There was no fluorescence in heart, liver, kidneys and spleen suggesting no detectable transfer of the siRNA from the lung to the circulation (figure 6A). Transfecting mice by oropharyngeal instillation with $\alpha \mathrm{ENaC}$ siRNA $(\mathrm{n}=7)$ or control siRNA $(\mathrm{n}=7)$ silenced $\alpha \mathrm{ENaC}$ by $30 \%$ at the mRNA level compared with control siRNA $(p<0.01)$ (figure 6B). Silencing of $\alpha \mathrm{ENaC} 1$ week after transfection remained at $23 \%$ compared with control siRNA (figure 6C; $\mathrm{n}=4$ for untreated, $\mathrm{n}=6$ for control siRNA and $\mathrm{n}=7$ for $\alpha \mathrm{ENaC}$ siRNA-treated mice) and was not significantly different from silencing at 48 hours. Repeated transfections with $\alpha \mathrm{ENaC}$ siRNA $(\mathrm{n}=8)$ demonstrated cumulative silencing, increasing to $58 \%$ reduction compared with control siRNA at 72 hours after the third instillation of $\alpha \mathrm{ENaC}$ siRNA (figure $6 \mathrm{D}$; online supplementary table S5).

The RTN siRNA formulations were well tolerated by the mice for single or triple dosing (online supplementary figure S6A,B). $\mathrm{H} \& \mathrm{E}$ staining of lung sections $(\mathrm{n}=3)$ showed that treatment with RTNs containing ENaC siRNA induced sporadic mild peribronchial cell infiltrates, the size and severity of which was unaffected by the number of instillations (figure 7A,B). Control siRNA induced a similar inflammatory response, although the foci were generally smaller and less frequent than with $\mathrm{ENaC}$ siRNA (figure 7C).

\section{DISCUSSION}

The lack of functional CFTR and hyperactivity of $\mathrm{ENaC}$ in the airways of patients with $\mathrm{CF}$ leads to disrupted ion and fluid homeostasis. ${ }^{3}$ Modulators of CFTR such as ivacaftor and the ivacaftor/lumacaftor (Orkambi) combination therapy offer treatment for patients with specific mutations, ${ }^{3435}$ but there are some mutation classes where CFTR modulators will not be effective, such as nonsense mutations, and so other therapeutic strategies are required. The low-volume hypothesis of CF lung disease links increased activity of $\mathrm{ENaC}$ with ASL depletion in $\mathrm{CF}^{3}$ and so reducing transepithelial sodium absorption through $\mathrm{ENaC}$ is an alternative target for therapeutics. ${ }^{11}{ }^{36}$ The role of $\mathrm{ENaC}$ in regulating ASL volume has been validated in recent work showing that inhibition of $\mathrm{ENaC}$ proteolytic activation using the SPLUNC1 or peptide fragments ${ }^{37-39}$ or QUB-TL1 $1^{40}$ successfully prevented dehydration of the ASL in CF HBEC monolayers. Small molecule inhibitors of $\mathrm{ENaC}$ suffer from rapid systemic absorption from the lung and are associated 
A

\begin{tabular}{ccc} 
Week & Week & Week \\
0 & $3-4$ & $5-6$ \\
\hline Cells on & Single & Triple \\
ALI & Transfection & Transfection \\
& (on alternate & days) \\
& -qRTPCR & -qRTPCR \\
& -Ussing & -ASL depth \\
& -CBF \\
& - -Vt \\
& & -Fluid Transport \\
& &
\end{tabular}

B

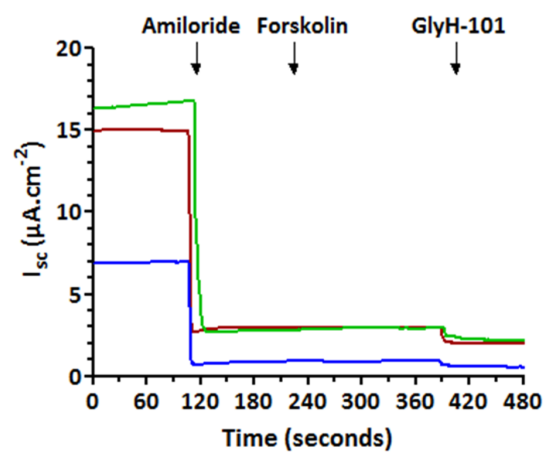

- Untreated

- Control siRNA

- $\alpha$ ENaC siRNA

C

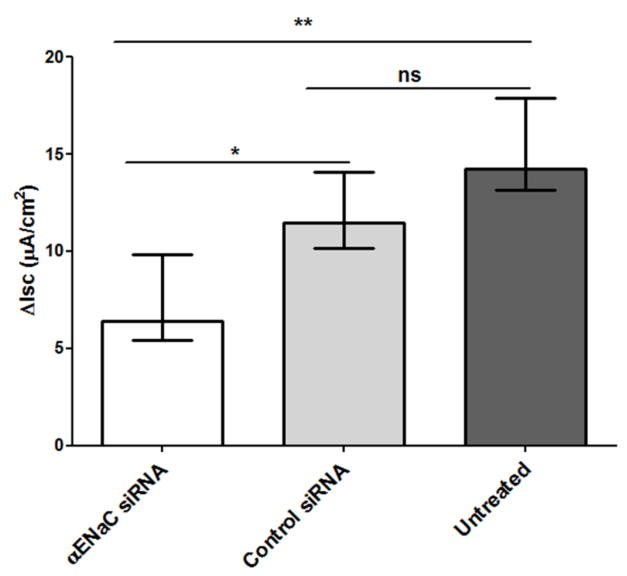

D

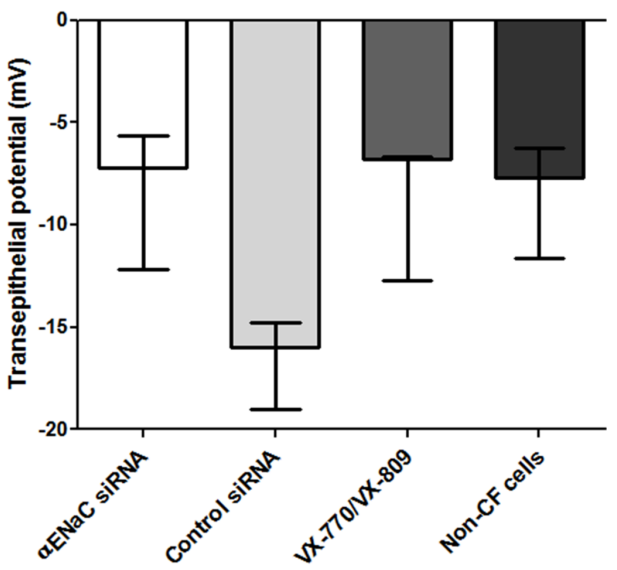

Figure 3 Single transfection of CFBE air-liquid interface (ALI) cell monolayers with nanocomplexes containing $\alpha$ ENaC siRNA reduces the amiloridesensitive short circuit current $\left(I_{\varsigma_{s}}\right)$. (A) A schematic highlighting experiments performed after single or triple transfections on CFBE cells grown at ALI. (B) Representative $I_{s c}$ traces from CFBE monolayers in Ussing chambers of cells treated with $100 \mathrm{nM} \alpha \mathrm{ENaC}$ siRNA or control siRNA or untreated cells. (C) The change in $\mathrm{I}_{s c}\left(\Delta \mathrm{I}_{\mathrm{sc}}\right)$ after application of $10 \mu \mathrm{M}$ amiloride is shown for the $\alpha \mathrm{ENaC}$ siRNA-treated cells (Ussing chambers; $\mathrm{n}=6$ ), the control siRNA-treated cells $(n=8)$ and the untreated CFBE cells $(n=5)$. Median values are presented as bars and IQR by upper and lower horizontal lines, with statistical significance determined by the non-parametric Mann-Whitney $\mathrm{U}$ test. Asterisks indicate comparisons of specific formulations with statistical significance $\left({ }^{*} p<0.05 ;{ }^{* *} p<0.01\right)$. (D) Transepithelial potential $\left(V_{t}\right)$ of $\alpha E N a C$ siRNA-treated monolayers of CFBE cells cultured for 4 weeks on ALI. Wells were triple-transfected with $100 \mathrm{nM} \alpha \mathrm{ENaC}$ siRNA $(n=5)$ or control siRNA $(n=5)$ and then $\mathrm{V}_{t}$ measurements performed 3 days after the last transfection using scanning ion-conductance microscopy (SICM). Further samples were treated with $10 \mu \mathrm{MVX}-8091$ day prior to $\mathrm{V}_{\mathrm{t}}$ measurement and treated with $10 \mu \mathrm{MVX}-770$ during measurement (for approximately $20 \mathrm{~min} ; \mathrm{n}=4$ ). Median values are presented as bars and IQR by upper and lower horizontal lines. Non-parametric Mann-Whitney U tests were performed, and no statistical significant differences were achieved. ASL, airway surface liquid; CBF, ciliary beat frequency; CFBE, cystic fibrosis bronchial epithelial cells; ENaC, epithelial sodium channel; siRNA, short interfering RNA.

with side effects such as hyperkalaemia due to $\mathrm{ENaC}$ inhibition in the kidney or pulmonary oedema. ${ }^{1141} 42$ We have therefore investigated $\mathrm{ENaC}$ silencing mediated by nanoparticles carrying siRNA.

We used siRNA to target the major subunit, $\alpha E N a C$. The $\alpha \mathrm{ENaC}$ subunit forms a sodium-conducting pore, while the other two subunits enhance its activity. ${ }^{43}$ The $\alpha$ subunit is critical for sodium transport function and volume regulation as demonstrated in $\alpha \mathrm{ENaC}$ knockout mice, which die soon after birth due to a failure to clear their lungs of fluid..$^{44}$ In addition, it has been shown that a low mRNA abundance of $\alpha \mathrm{ENaC}$ in the nasal epithelium of premature infants is linked with respiratory 
A

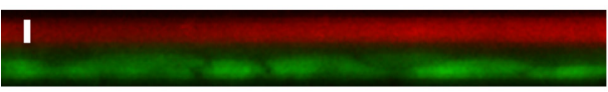

I

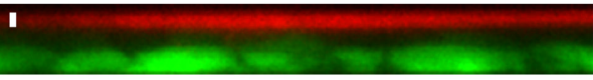

I

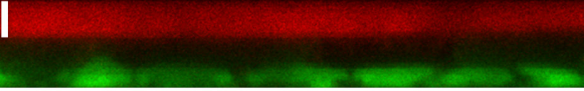

$C$

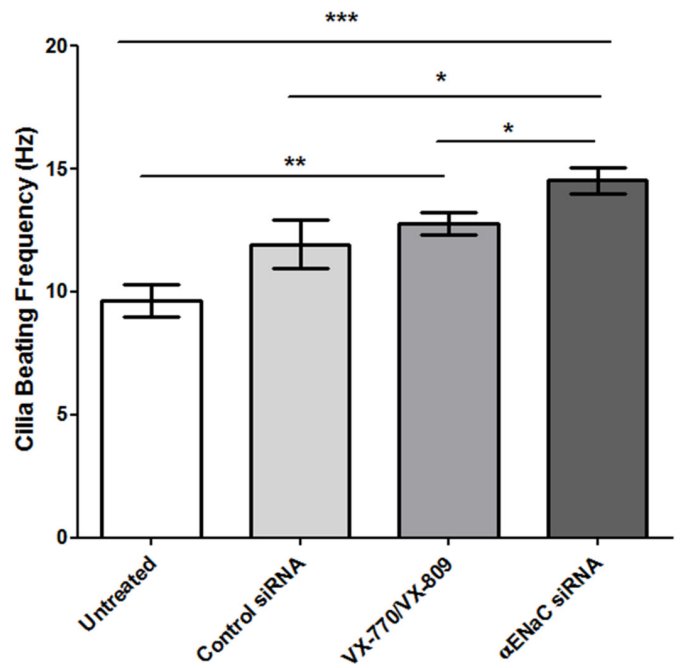

B

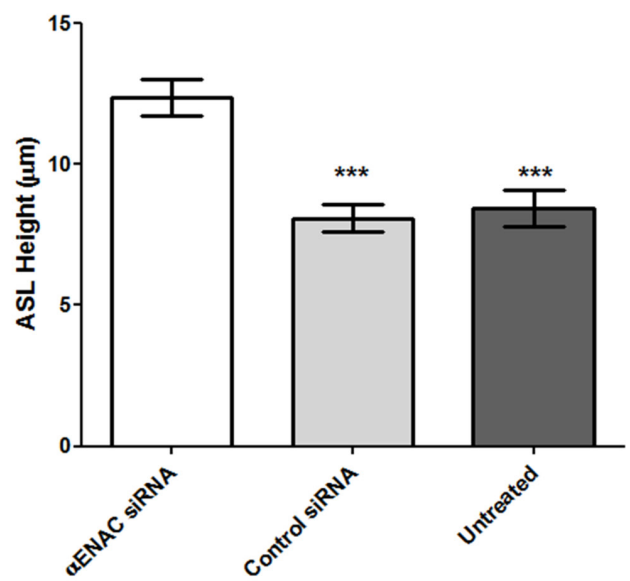

D

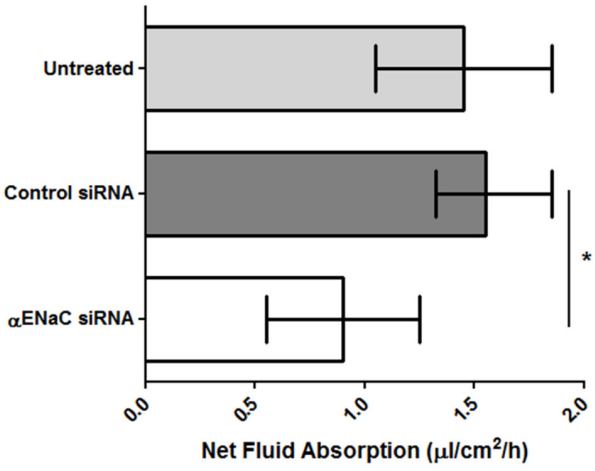

Figure 4 Effect of triple transfections of CFBE ALI cells with nanocomplexes containing $\alpha$ ENaC siRNA. The CFBE cells were cultured in snapwells for 4 weeks then treated with $100 \mathrm{nM} \alpha \mathrm{ENaC}$ siRNA or control siRNA at 48 hours intervals and the measurements performed 3 days after the third dose. (A) ASL depth measurements of CFBE monolayers as determined by confocal microscopy. XZ representative images of fluorescently labelled ASL (red) and cells (green). Top: untreated cells, middle: cells transfected three times with $100 \mathrm{nM}$ of control siRNA and bottom: cells transfected three times with $100 \mathrm{nM}$ of $\alpha \mathrm{ENaC}$ siRNA. A white bar has been included to denote the ASL measurement. (B) ASL depth measurement of each treatment group $(n=4)$. Bars represent mean $\pm S E M$, while asterisks indicate statistical significance of comparisons between the $\alpha$ ENaC siRNA-treated cells versus the controls $\left({ }^{* *} p<0.001\right)$ determined by an ANOVA test followed by Bonferroni's post hoc test. (C) Effect of $\alpha$ ENaC siRNA, control siRNA and VX-770 and VX-809 on ciliary beat frequency (CBF) of CFBE cells grown at ALI. For each experimental condition $(n=10)$, readings of CBF were calculated from 10 ciliated areas in the snapwell, and the data represent the mean \pm SEM. Asterisks indicate comparisons of specific formulations with statistical significance $\left({ }^{*} p<0.05 ;{ }^{* *} p<0.01 ;{ }^{* *} p<0.001\right)$ determined by an ANOVA test followed by Bonferroni's post hoc test. (D) Transepithelial fluid transport through human CFBE cells. Net fluid absorption rate was measured 4 days after cell treatment with a control siRNA or with $\alpha$ ENaC siRNA. Bars represent the median value with IQR shown by the horizontal lines $(n=4)$, while asterisks indicate statistical significance $\left({ }^{*} p<0.05\right)$ determined by non-parametric Mann-Whitney U tests. ALI, air-liquid interface; ASL, airway surface liquid; CFBE, cystic fibrosis bronchial epithelial cells; ENaC, epithelial sodium channel; siRNA, short interfering RNA.

failure. ${ }^{45}$ Lastly, a mutation that leads to $\alpha \mathrm{ENaC}$ hyperactivity was found in patients with atypical $\mathrm{CF}{ }^{46}$

Nanoparticles offer protection to the siRNA during nebulisation and from nuclease attack in lung fluids and enable penetration of extracellular barriers such as mucus and the PCL ${ }^{47}$ before entering the epithelial cells by endocytosis. RTNs, comprising the oligolysine epithelial-targeting peptide (peptide E) and the liposome DOTMA/DOPE, self-assemble on mixing lipid and peptide components with siRNA to form cationic, monodisperse nanoparticles with a size of approximately $90 \mathrm{~nm}$, which have been used previously for lung delivery of nucleic acids (including by nebulisation) in mice and pigs. ${ }^{2526303148}$ Similar RTN formulations can package and transfect siRNA efficiently, ${ }^{2023249}$ and so we are now investigating use of $\alpha \mathrm{ENaC}$ siRNA to assess its therapeutic potential in epithelial lung models in vitro and in vivo.

We first assessed the ability of RTNs to penetrate mucus, which presents a physical barrier to nanoparticle siRNA delivery in the airways. Mucus is a gel-like layer, rich in charged mucin glycoproteins covering the lung epithelium and is particularly thick and sticky in the CF lung. ${ }^{50} 51$ Differentiated ALI cultures of human airway epithelial cells produce copious amounts of 
A

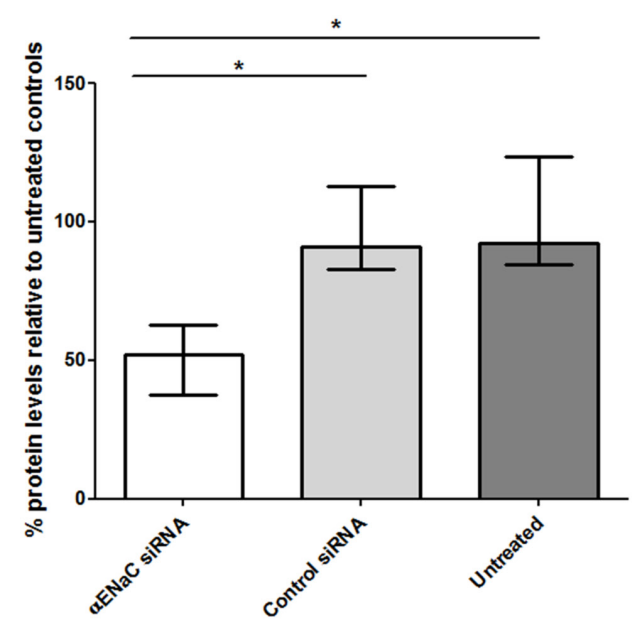

C

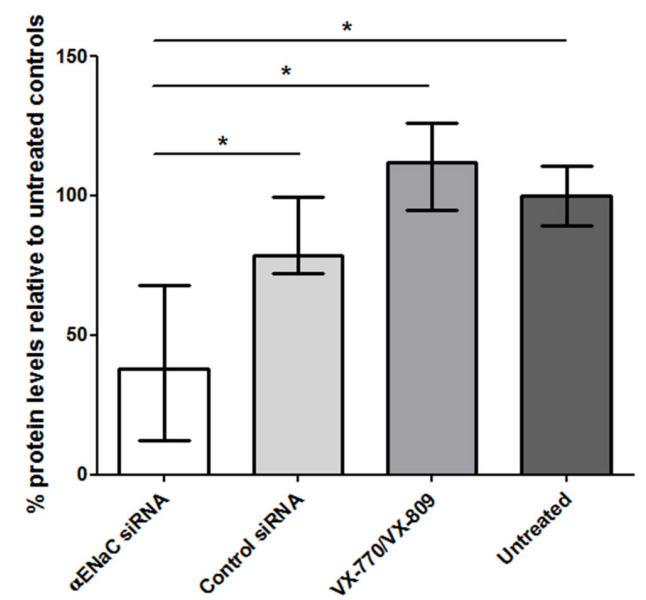

B

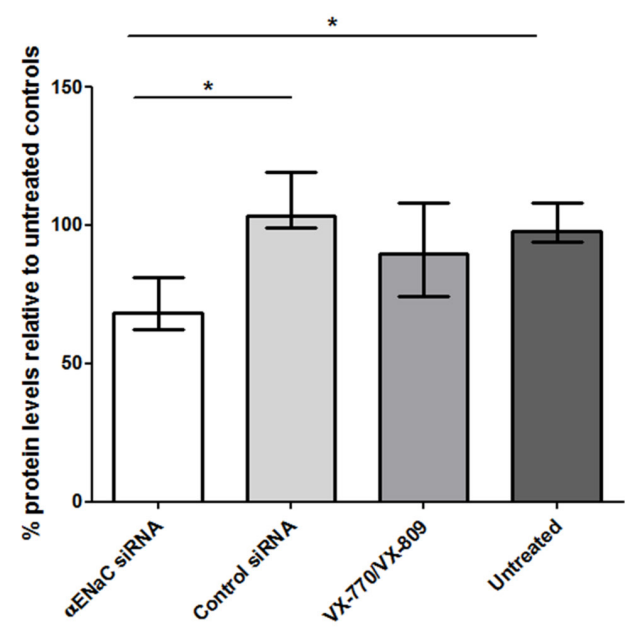

D

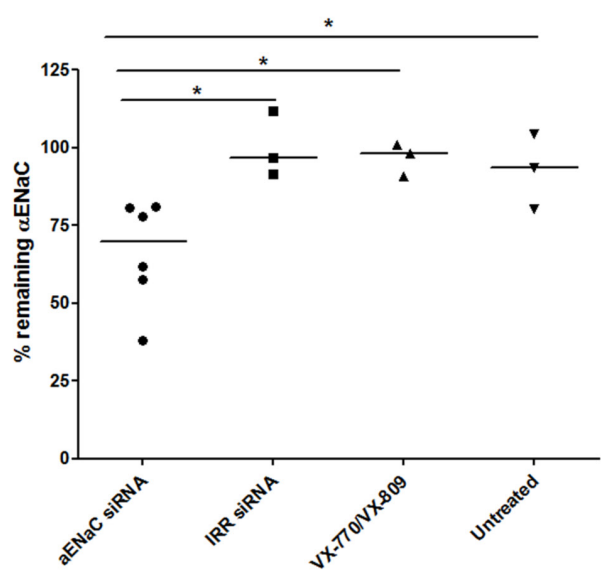

Figure 5 Protein concentration in mucus collected at different time points from transfected or untreated CFBE cells grown at ALI and in vitro silencing after three transfections. Mucus collections were done (A) 2 days after the first transfection ( $\alpha E N a C$ siRNA treated, $n=6$; control siRNA treated, $n=3$; untreated controls, $n=3$ ), (B) 2 days after the second transfection ( $\alpha E N a C$ siRNA treated, $n=6$; control siRNA treated, $n=3 ; \mathrm{VX}-770$ and VX-809 treated, $n=3$; untreated controls, $n=3$ ) and (C) 7 days after the third transfection ( $\alpha E N a C$ siRNA treated, $n=6$; control siRNA treated, $n=3$; VX-770 and VX-809 treated, $n=3$; untreated controls, $n=3$ ). The concentration levels were normalised to those of the untreated cells. (D) Formulations containing either $100 \mathrm{nM} \alpha \mathrm{ENaC}$ siRNA $(n=6)$ or control siRNA $(n=3)$ were used in three sequential transfections of CFBE-BMI-1 cells grown at ALI for 4 weeks, and the percentage of silencing was calculated 8 days after the third transfection. Silencing was normalised to the mean control siRNA set at $100 \%$. The middle horizontal lines represent the median values. Asterisks indicate comparisons of specific formulations with statistical significance $\left({ }^{*} p<0.05\right)$ determined by non-parametric Mann-Whitney U tests. ALI, air-liquid interface; CFBE, cystic fibrosis bronchial epithelial cells; ENaC, epithelial sodium channel; siRNA, short interfering RNA.

mucus, which is particularly viscous from CF cells. ${ }^{52}$ RTN diffusion in mucus from three sources was used including porcine gastric mucus and human mucus from differentiated $\mathrm{CF}$ and non-CF airway epithelial cultures. RTN diffusion rates were lowest in CF mucus, consistent with its increased viscosity. RTNs diffused at similar rates to siRNA alone in CF and non-CF mucus despite their size and charge differences. The diffusion rates of RTNs were greater than those of cationic PS nanoparticles of similar size used in cervicovaginal mucus, ${ }^{53}{ }^{54}$ suggesting that surface properties of RTNs contribute to their mucus mobility. ${ }^{32}$

Silencing levels of $\alpha \mathrm{ENaC}$ by $30 \%$ from a single dose were achieved, which resulted in a significant reduction in amiloride-sensitive $\mathrm{I}_{\mathrm{sc}}$ compared with control siRNA and untransfected cells. Silencing did not affect $R_{t}$ indicating that there was no damage to the epithelial tight junctions by the nanoparticle complex directly or by decreased cell viability and that the changes in $\mathrm{I}_{\mathrm{sc}}$ were a direct effect of reduced $\alpha \mathrm{ENaC}$ activity. Interestingly $\beta \mathrm{ENaC}$, but not $\gamma \mathrm{ENaC}$, was also silenced by $\alpha \mathrm{ENaC}$ siRNA. This was observed in other studies, ${ }^{17}$ suggesting transcriptional feedback inhibition of $\beta \mathrm{ENaC}$ by $\alpha \mathrm{ENaC}$.

Enhancement of silencing of $\alpha$ ENAC to $50 \%$ by three sequential transfections in CFBE cells reduced the transepithelial potential to normal range values $(-7 \mathrm{mV})$ in ALI cultures. ${ }^{55}$ This may be a useful therapeutic biomarker as CF individuals display hyperpolarised nasal transepithelial potentials. ${ }^{56}$ Silencing of $\alpha$ ENAC also caused a significant reduction in fluid absorption and increased ASL depth to normal levels. Increased hydration of the epithelial surface was also indicated by the reduced total protein concentration in mucus washings from $\alpha \mathrm{ENaC}$ siRNAtreated cultures for at least a week post-transfection, whereas 
A

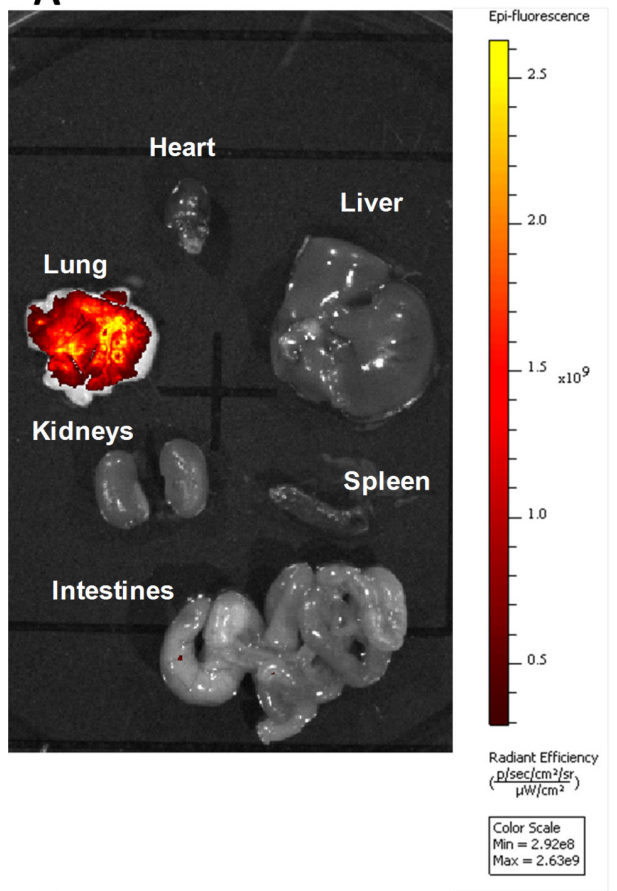

C

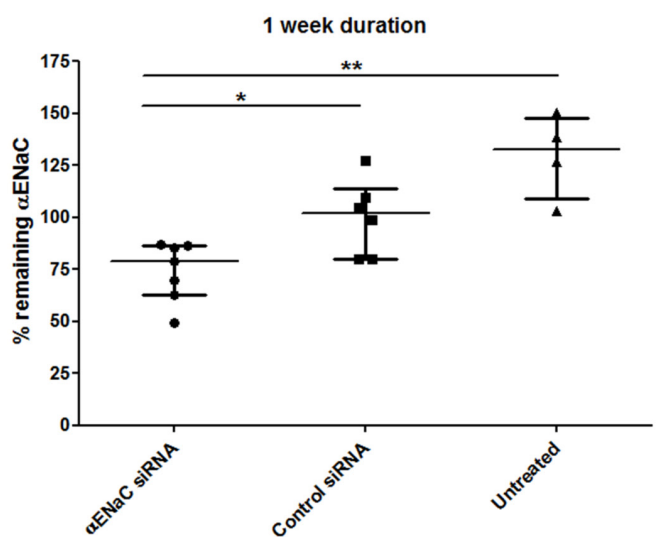

B

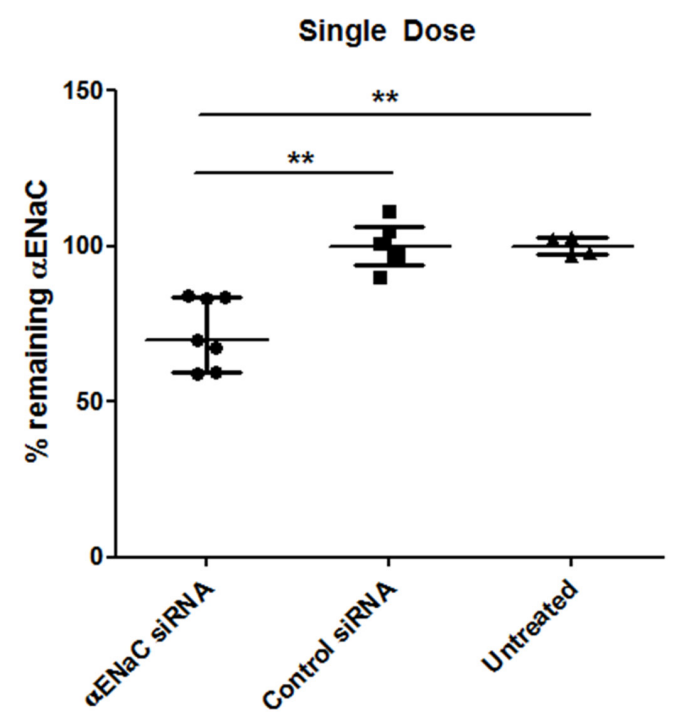

D

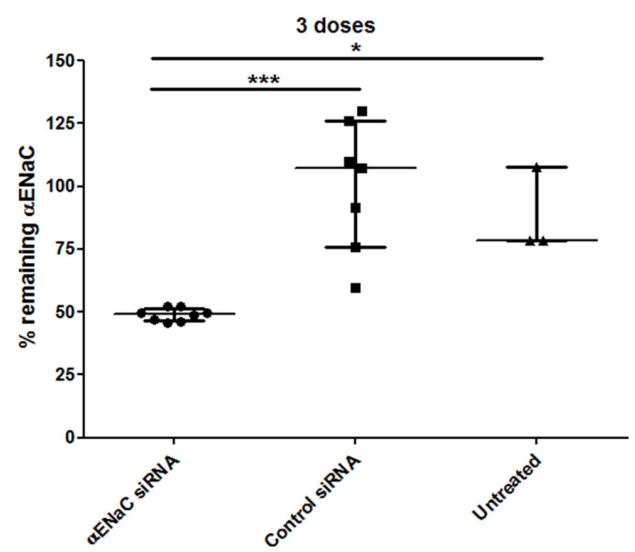

Figure 6 In vivo lung administration of siRNA-containing nanocomplexes. (A) Uptake of Dy677-siRNA formulations following oropharyngeal administration. Twenty-four hours later, the mice were culled ( $n=3$ per group), and organs (heart, lung, liver, kidneys, spleen and intestines) were extracted and imaged for fluorescence. (B-D) The remaining $\alpha E N a C$ mRNA was quantified by qRT-PCR in C57BL6 female mice after instillation of cationic nanocomplexes containing $16 \mu \mathrm{g} \alpha \mathrm{ENaC}$ siRNA ( $n=7)$ or control siRNA ( $n=6)$ at (B) 48 hours and (C) 7 days. (D) The amount of remaining $\alpha$ ENaC mRNA detected by qRT-PCR in C57BL6 female mice at 72 hours after the last of three instillations of cationic nanocomplexes containing $16 \mu \mathrm{g}$ $\alpha$ ENaC siRNA $(n=8)$ or control siRNA $(n=7)$. Silencing was normalised to the mean control siRNA set at $100 \%$. Medians and IQRs are presented by horizontal lines. Asterisks indicate comparisons of specific formulations with statistical significance $\left({ }^{*} p<0.05 ;{ }^{* *} p<0.01 ;{ }^{* * *} p<0.001\right)$ determined by non-parametric Mann-Whitney U tests. ENaC, epithelial sodium channel; siRNA, short interfering RNA.

the CFTR potentiator/corrector drug combination, VX-770 and VX-809, showed no effect on mucus protein concentration.

We further hypothesised that increased ASL depth would reduce impedance of ciliary motility. Indeed, we found that the CBF in ENaC siRNA-treated CF cells was increased to $\sim 15 \mathrm{~Hz}$, which compares well with normal CBF of approximately $16 \mathrm{~Hz} .^{57}$ Furthermore, the siRNA induced changes in CBF and fluid height after three doses, which was consistent with that reported for current drugs used to correct CFTR activity. VX-770 on its own increased CBF, ${ }^{58}$ whereas the VX-770 and VX-809 combination increased ASL height ${ }^{59}$ (both studies following five consecutive day treatments).

This study suggests that silencing $\mathrm{ENaC}$ in the range of $30 \%-50 \%$ is sufficient for restoration of epithelial ion transport balance, fluid transport and mucociliary properties. In previous $\alpha \mathrm{ENaC}$ silencing studies with siRNA, transfections were performed pre-ALI as transfections at ALI were ineffective, ${ }^{18}$ although they reported correction of the short circuit current and increased ASL when using siRNAs targeting both $\alpha$ and BENaC. ${ }^{18}$ Another study showed that silencing of $\alpha \mathrm{ENaC}$ with a commercial transfection reagent in submerged cultures lasted for at least 3 days, although they did not perform transfections at ALI. ${ }^{13}$ They also reported $35 \%-40 \%$ silencing in vivo with a liposomal formulation from a single administration that persisted at least 72 hours. ${ }^{13}$ Finally, an shRNA approach following lentiviral transduction of immortalised and primary cell lines used $\alpha \mathrm{ENaC}$ as their target. ${ }^{12}$ The authors transduced primary cells before the formation of tight junctions, unlike our fully differentiated cell 
A

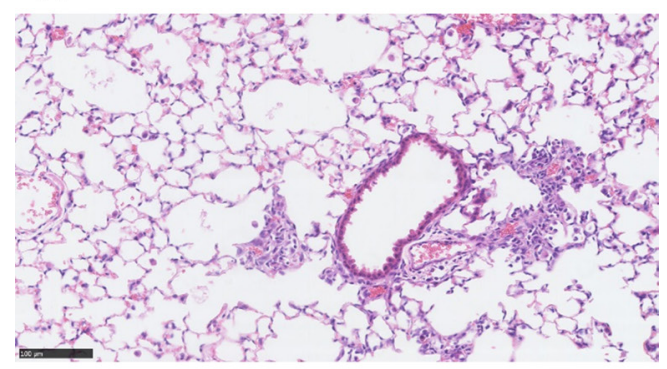

B

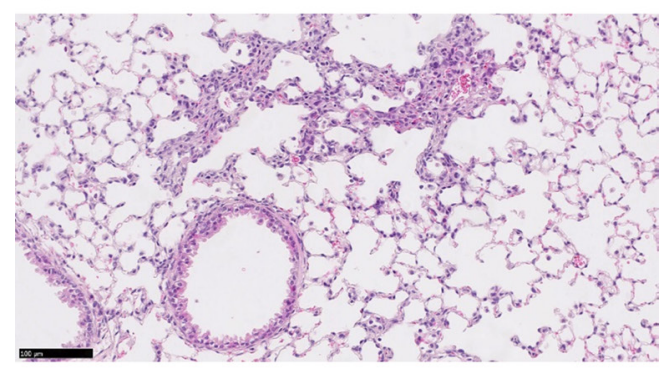

C

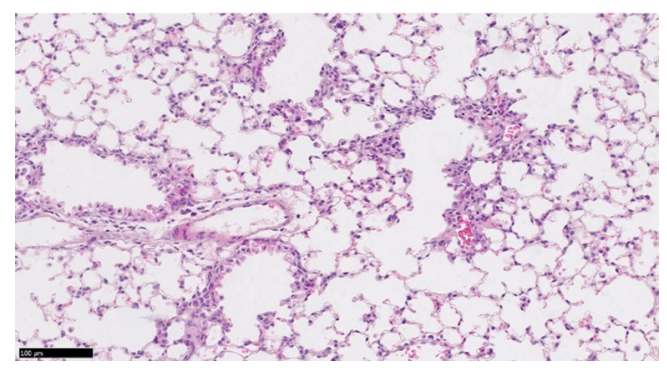

Figure 7 In vivo delivery of siRNA-containing nanocomplexes. Representative images of H\&E stained murine lung sections following single (A) and triple (B) instillations of cationic $\alpha E N a C$ siRNA nanocomplexes ( $n=3$ for both), or a triple instillation $(n=3)$ of cationic control siRNA nanocomplexes (C). All triple-instilled treated mice received three doses of nanocomplexes containing $16 \mu \mathrm{g}$ siRNA on alternate days, and the lungs were harvested 48 hours after the third instillation. The mice that had one instillation of nanocomplexes containing $16 \mu \mathrm{g}$ siRNA, also had their lungs harvested 48 hours following instillation. Scale bars $=100 \mu \mathrm{m}$. siRNA, short interfering RNA. only minimal focal inflammation assessed histologically and the nanocomplex biodistribution was restricted to the lungs. Transfection experiments at ALI with human CFBE cells suggested that silencing of $\alpha \mathrm{ENaC}$ in the range of $30 \%-50 \%$ was sufficient for restoration of epithelial ion transport balance, fluid transport and mucociliary properties. We have shown that RTNs achieve these levels of silencing in mice and that the silencing is persistent for at least 1 week. These findings support the translational potential of this nanoparticle-mediated siRNA therapy for CF.

In summary, we have described nanoparticles that can penetrate mucus effectively and deliver siRNA to the airway epithelium and that silencing of $\alpha \mathrm{ENaC}$ can be achieved in vitro and in vivo leading to improved hydration and mucociliary function in CFBE monolayers. Other studies have also shown functional correction of airway epithelial cells but only by transfection prior to ALI culture. RTNs represent a powerful new tool for siRNA transfection studies in differentiated respiratory epithelial cells and in vivo. The potential to regulate $\mathrm{ENaC}$ to a minimally effective level, the persistence of silencing for at least 1 week and restriction of distribution to the lung after airway administration indicates translational potential and suggests advantages in efficacy and safety over orally administered, small molecule drugs.

Contributors ADT, CO, DLB, SAJ, GWJM, RJM and SLH designed the study. ADT, MMM, RI, HC, CMS, LZR, AMA, JLB, DM, KNK and SAJ performed experiments and analysed data. ADT and SLH wrote the manuscript with all other authors contributing relevant sections, comments and proofreading the manuscript.

Funding This work was funded by the Cystic Fibrosis Trust and Action Medical Research (reference number: GN2299) and the Wellcome Trust (WT094348MA). This work was also supported by the National Institute for Health Research Biomedical Research Centre at Great Ormond Street Hospital for Children NHS Foundation Trust and University College London.

Competing interests SLH holds equity in Nanogenic Solutions Ltd, a company developing commercial opportunities with the LPR technology. SLH and ADT receive consultancy fees from Ryboquin Ltd in relation to the development of LPR technology for cancer therapies. Other authors have no competing interests to declare.

Patient consent Not required.

Provenance and peer review Not commissioned; externally peer reviewed.

Open access This is an open access article distributed in accordance with the terms of the Creative Commons Attribution (CC BY 4.0) license, which permits others to distribute, remix, adapt and build upon this work, for commercial use, provided the original work is properly cited. See: http://creativecommons.org/licenses/by/4.0/

(C) Article author(s) (or their employer(s) unless otherwise stated in the text of the article) 2018. All rights reserved. No commercial use is permitted unless otherwise expressly granted.

\section{REFERENCES} ings, they have shown that reducing mRNA results in proportional changes in the short circuit current responses and also reduced net apical to basal fluid flux. In addition, they demonstrated that, at a high lentiviral dose, the $\beta E N a C$ mRNA was reduced, but $\gamma \mathrm{ENaC}$ was not, which is in agreement with our findings.

We finally quantified $\mathrm{ENaC}$ silencing, after single or repeat siRNA dosing (by oropharyngeal instillation) in the lungs of normal mice. The tolerance of repeated dosing supports the hypothesis that our nanoparticles do not induce neutralising antibodies, which is important for a potential life-long therapy. Minimal effective modulation of $\mathrm{ENaC}$ activity by repeated dosing of siRNA is likely to be much safer than complete inactivation of $\alpha \mathrm{ENaC}$, since this could result in negative effects such as oedema observed in lungs of ENaC knockout mice. ${ }^{44}$ There were no significant adverse effects of repeated dosing of RTNs in mice as judged by body weight and behaviour. There was
1 Gadsby DC, Vergani P, Csanády L. The ABC protein turned chloride channel whose failure causes cystic fibrosis. Nature 2006;440:477-83.

2 Riordan JR, Rommens JM, Kerem B, et al. Identification of the cystic fibrosis gene: cloning and characterization of complementary DNA. Science 1989;245:1066-73.

3 Boucher RC. Cystic fibrosis: a disease of vulnerability to airway surface dehydration. Trends Mol Med 2007;13:231-40.

4 Donaldson SH, Boucher RC. Sodium channels and cystic fibrosis. Chest 2007;132:1631-6.

5 Barker PM, Nguyen MS, Gatzy JT, et al. Role of gammaENaC subunit in lung liquid clearance and electrolyte balance in newborn mice. Insights into perinatal adaptation and pseudohypoaldosteronism. J Clin Invest 1998;102:1634-40.

6 Bonny O, Chraibi A, Loffing J, et al. Functional expression of a pseudohypoaldosteronism type I mutated epithelial $\mathrm{Na}+$ channel lacking the pore-

7 McDonald FJ, Yang B, Hrstka RF, et al. Disruption of the beta subunit of the epithelial $\mathrm{Na}+$ channel in mice: hyperkalemia and neonatal death associated with a pseudohypoaldosteronism phenotype. Proc Natl Acad Sci U S A 1999;96:1727-31.

8 Giraldez T, Rojas P, Jou J, et al. The epithelial sodium channel $\delta$-subunit: new notes for an old song. Am J Physiol Renal Physiol 2012;303:F328-F338. forming region of its alpha subunit. J Clin Invest 1999;104:967-74. 
9 Hofmann T, Senier I, Bittner P, et al. Aerosolized amiloride: dose effect on nasal bioelectric properties, pharmacokinetics, and effect on sputum expectoration in patients with cystic fibrosis. J Aerosol Med 1997;10:147-58.

10 Hirsh AJ, Sabater JR, Zamurs A, et al. Evaluation of second generation amiloride analogs as therapy for cystic fibrosis lung disease. J Pharmacol Exp Ther 2004:311:929-38.

11 Butler R, Hunt T, Smith NJ. ENaC inhibitors for the treatment of cystic fibrosis. Pharm Pat Anal 2015:4:17-27.

12 Aarbiou J, Copreni E, Buijs-Offerman RM, et al. Lentiviral small hairpin RNA delivery reduces apical sodium channel activity in differentiated human airway epithelial cells. I Gene Med 2012;14:733-45.

13 Clark KL, Hughes SA, Bulsara P, et al. Pharmacological characterization of a nove ENaC $\alpha$ siRNA (GSK2225745) with potential for the treatment of cystic fibrosis. Mol Ther Nucleic Acids 2013;2:e65.

14 Ramachandran S, Krishnamurthy S, Jacobi AM, et al. Efficient delivery of RNA interference oligonucleotides to polarized airway epithelia in vitro. Am J Physiol Lung Cell Mol Physiol 2013;305:L23-L32.

15 Draz MS, Fang BA, Zhang P, et al. Nanoparticle-mediated systemic delivery of siRNA for treatment of cancers and viral infections. Theranostics 2014:4:872-92.

16 Di Gioia S, Trapani A, Castellani S, et al. Nanocomplexes for gene therapy of respiratory diseases: Targeting and overcoming the mucus barrier. Pulm Pharmacol Ther 2015:34:8-24.

17 Caci E, Melani R, Pedemonte $N$, et al. Epithelial sodium channel inhibition in primary human bronchial epithelia by transfected siRNA. Am J Respir Cell Mol Biol 2009;40:211-6.

18 Gianotti A, Melani R, Caci E, et al. Epithelial sodium channel silencing as a strategy to correct the airway surface fluid deficit in cystic fibrosis. Am J Respir Cell Mol Biol 2013:49:445-52.

19 Tagalakis AD, Castellaro S, Zhou H, et al. A method for concentrating lipid peptide DNA and siRNA nanocomplexes that retains their structure and transfection efficiency. Int J Nanomedicine 2015;10:2673-83.

20 Tagalakis AD, He L, Saraiva L, et al. Receptor-targeted liposome-peptide nanocomplexes for siRNA delivery. Biomaterials 2011:32:6302-15.

21 Tagalakis AD, Lee DH, Bienemann AS, et al. Multifunctional, self-assembling anionic peptide-lipid nanocomplexes for targeted siRNA delivery. Biomaterials 2014;35:8406-15.

22 Tagalakis AD, Maeshima R, Yu-Wai-Man C, et al. Peptide and nucleic acid-directed self-assembly of cationic nanovehicles through giant unilamellar vesicle modification: targetable nanocomplexes for in vivo nucleic acid delivery. Acta Biomater 2017:51:351-62.

23 Tagalakis AD, Saraiva L, McCarthy D, et al. Comparison of nanocomplexes with branched and linear peptides for siRNA delivery. Biomacromolecules 2013;14:761-70.

24 Weng A, Manunta MD, Thakur M, et al. Improved intracellular delivery of peptide- and lipid-nanoplexes by natural glycosides. J Control Release 2015;206:75-90.

25 Tagalakis AD, McAnulty RJ, Devaney J, et al. A receptor-targeted nanocomplex vector system optimized for respiratory gene transfer. Mol Ther 2008;16:907-15.

26 Manunta MD, McAnulty RJ, Tagalakis AD, et al. Nebulisation of receptor-targeted nanocomplexes for gene delivery to the airway epithelium. PLoS One 2011;6:e26768

27 Bella J, Kolatkar PR, Marlor CW, et al. The structure of the two amino-termina domains of human ICAM-1 suggests how it functions as a rhinovirus receptor and as an LFA-1 integrin ligand. Proc Natl Acad Sci U S A 1998;95:4140-5.

28 Chan SC, Shum DK, Tipoe GL, et al. Upregulation of ICAM-1 expression in bronchial epithelial cells by airway secretions in bronchiectasis. Respir Med 2008;102:287-98.

29 Du Z, Munye MM, Tagalakis AD, et al. The role of the helper lipid on the DNA transfection efficiency of lipopolyplex formulations. Sci Rep 2014;4:7107.

30 Munye MM, Tagalakis AD, Barnes JL, et al. Minicircle DNA provides enhanced and prolonged transgene expression following airway gene transfer. Sci Rep 2016;6:23125

31 Manunta MDI, Tagalakis AD, Attwood M, et al. Delivery of ENaC siRNA to epithelial cells mediated by a targeted nanocomplex: a therapeutic strategy for cystic fibrosis. Sci Rep 2017;7:700.

32 Schroeder A, Levins CG, Cortez C, et al. Lipid-based nanotherapeutics for siRNA delivery. J Intern Med 2010:267:9-21.

33 Munye MM, Shoemark A, Hirst RA, et al. BMI-1 extends proliferative potential of human bronchial epithelial cells while retaining their mucociliary differentiation capacity. Am J Physiol Lung Cell Mol Physiol 2017;312:L258-L267.
34 Wainwright CE, Elborn JS, Ramsey BW, et al. Lumacaftor-Ivacaftor in Patients with Cystic Fibrosis Homozygous for Phe508del CFTR. N Engl J Med 2015;373:220-31.

$35 \mathrm{Yu} \mathrm{H}$, Burton B, Huang CJ, et al. Ivacaftor potentiation of multiple CFTR channels with gating mutations. J Cyst Fibros 2012;11:237-45

36 Burrows EF, Southern KW, Noone PG. Sodium channel blockers for cystic fibrosis. Cochrane Database Syst Rev 2014:CD005087.

37 Garcia-Caballero A, Rasmussen JE, Gaillard E, et al. SPLUNC1 regulates airway surface liquid volume by protecting ENaC from proteolytic cleavage. Proc Natl Acad Sci U S A 2009:106:11412-7.

38 Hobbs CA, Blanchard MG, Alijevic O, et al. Identification of the SPLUNC1 ENaCinhibitory domain yields novel strategies to treat sodium hyperabsorption in cystic fibrosis airway epithelial cultures. Am J Physiol Lung Cell Mol Physiol 2013;305:L99 0-L1001.

39 Hobbs CA, Da Tan C, Tarran R. Does epithelial sodium channel hyperactivity contribute to cystic fibrosis lung disease? J Physiol 2013:591:4377-87.

40 Reihill JA, Walker B, Hamilton RA, et al. Inhibition of protease-epithelial sodium channel signaling improves mucociliary function in cystic fibrosis airways. Am J Respir Crit Care Med 2016;194:701-10.

41 Almaça J, Faria $D$, Sousa $M$, et al. High-content siRNA screen reveals global ENaC regulators and potential cystic fibrosis therapy targets. Cell 2013;154:1390-400.

42 O'Riordan TG, Donn KH, Hodsman P, et al. Acute hyperkalemia associated with inhalation of a potent ENaC antagonist: Phase 1 trial of GS-9411. J Aerosol Med Pulm Drug Deliv 2014;27:200-8

43 Alvarez de la Rosa D, Canessa CM, Fyfe GK, et al. Structure and regulation of amiloride-sensitive sodium channels. Annu Rev Physiol 2000;62:573-94.

44 Hummler E, Barker P, Gatzy J, et al. Early death due to defective neonatal lung liquid clearance in alpha-ENaC-deficient mice. Nat Genet 1996;12:325-8.

45 Helve $\mathrm{O}$, Pitkänen $\mathrm{OM}$, Andersson $\mathrm{S}$, et al. Low expression of human epithelial sodium channel in airway epithelium of preterm infants with respiratory distress. Pediatrics 2004;113:1267-72.

46 Rauh R, Diakov A, Tzschoppe A, et al. A mutation of the epithelial sodium channel associated with atypical cystic fibrosis increases channel open probability and reduces $\mathrm{Na}+$ self inhibition. J Physiol 2010:588:1211-25.

47 Button B, Cai LH, Ehre C, et al. A periciliary brush promotes the lung health by separating the mucus layer from airway epithelia. Science 2012:337:937-41.

48 Manunta MD, McAnulty RJ, McDowell A, et al. Airway deposition of nebulized gene delivery nanocomplexes monitored by radioimaging agents. Am J Respir Cell Mol Biol 2013;49:471-80.

49 Yu-Wai-Man C, Tagalakis AD, Manunta MD, et al. Receptor-targeted liposomepeptide-siRNA nanoparticles represent an efficient delivery system for MRTF silencing in conjunctival fibrosis. Sci Rep 2016;6:21881.

50 Duncan GA, Jung J, Hanes J, et al. The mucus barrier to inhaled gene therapy. Mol Ther 2016:24:2043-53.

51 Voynow JA, Rubin BK. Mucins, mucus, and sputum. Chest 2009:135:505-12.

52 Derichs $N$, Jin BJ, Song Y, et al. Hyperviscous airway periciliary and mucous liquid layers in cystic fibrosis measured by confocal fluorescence photobleaching. Faseb J 2011;25:2325-32.

53 Lai SK, O'Hanlon DE, Harrold S, et al. Rapid transport of large polymeric nanoparticles in fresh undiluted human mucus. Proc Natl Acad Sci U S A 2007;104:1482-7.

54 Wang YY, Lai SK, Suk JS, et al. Addressing the PEG mucoadhesivity paradox to engineer nanoparticles that "slip" through the human mucus barrier. Angew Chem Int Ed Engl 2008;47:9726-9.

55 Tarran R, Trout L, Donaldson SH, et al. Soluble mediators, not cilia, determine airway surface liquid volume in normal and cystic fibrosis superficial airway epithelia. J Gen Physiol 2006;127:591-604.

56 Sermet-Gaudelus I, Girodon E, Roussel D, et al. Measurement of nasal potentia difference in young children with an equivocal sweat test following newborn screening for cystic fibrosis. Thorax 2010;65:539-44.

57 Smith CM, Djakow J, Free RC, et al. ciliaFA: a research tool for automated, highthroughput measurement of ciliary beat frequency using freely available software. Cilia 2012;1:14.

58 Van Goor F, Hadida S, Grootenhuis PD, et al. Rescue of CF airway epithelial cell function in vitro by a CFTR potentiator, VX-770. Proc Natl Acad Sci U SA 2009:106:18825-30.

59 Van Goor F, Hadida S, Grootenhuis PD, et al. Correction of the F508del-CFTR protein processing defect in vitro by the investigational drug VX-809. Proc Natl Acad Sci U SA 2011;108:18843-8. 